\title{
PEMBELAJARAN FISIKA KONSEP KALOR DENGAN MENGGUNAKAN MEDIA PIROLISIS SAMPAH PLASTIK UNTUK MENINGKATKAN KETRAMPILAN BERPIKIR KRITIS SISWA DI SMAN 3 BENGKULU TENGAH
}

\author{
(Learning Physics Concept Physics using Plastic Waste Pirolysis Media to \\ Increase Student Critical Thinking Skills in SMAN 3 Bengkulu Tengah) \\ Umi Kalsum ${ }^{1 *}$, Agus Sundaryono ${ }^{1}$ dan Muhammad Farid ${ }^{2}$ \\ ${ }^{1}$ Mahasiswa Program studi S-2 Pendidikan IPA Universitas Bengkulu \\ ${ }^{2}$ Dosen Program studi S-2 Pendidikan IPA Universitas Bengkulu \\ ${ }^{3}$ Dosen FMIPA Universitas Bengkulu, Indonesia \\ *cahayabintang259@gmail.com
}

\begin{abstract}
.
The objectives of this research are (1) to know the value of density, viscosity, fog point, oil absorption caloric, odor, color and fire sensitivity, in pyrolysis of plastic garbage from condenser one and two adsorbed using zeolite and activated charcoal, (2) the content contained in pyrolysis plastic waste oil adsorbed using active zeolite and charcoal, (3) knowing differences in critical thinking skills among students who learn to use guided inquiry learning model with students who study conventionally on physics learning. Convert plastic waste into fuel oil using a pyrolysis process with two water condensers, then plastic waste pyrolysis oil adsorbed using activated zeolite and charcoal. The results showed that the density value of the adsorbed oil for one condenser was $772 \mathrm{Kg} / \mathrm{m} 3$ and the condenser was $770 \mathrm{Kg} \mathrm{/} \mathrm{m3}$, the viscosity value of the adsorbed oil from the condenser one and two had the same value of $0.49 \mathrm{~m} 2 / \mathrm{s}$, the fog point value oil that has been adsorbed on the condenser yield one and two is the same value that is $-180 \mathrm{C}$, the calorific value of oil absorption, color, odor, and fire sensitivity shows the more adsorbent and the longer the adsorption process, the oil absorbs the smaller, , the odor does not sting, and the fire sensitivity gets smaller. GC-MS test results obtained the most compounds contained in pyrolysis oil plastic waste that has been adsorbed that is 1,3,5trimethylcyclohexene. The implementation of physics learning on the concept of heat shows that there are differences in critical thinking skills in control and experiment class. Based on different test on posttest result the first material got 0,022 and postest second material equal to 0,047 , the value is smaller than level of significance 0,05 so $\mathrm{Ha}$ accepted.
\end{abstract}

Keywords: Active Charcoal, Heat, Critical Thinking Skill, Pyrolysis, Zeolite

\begin{abstract}
ABSTRAK.
Penelitian ini bertujuan untuk (1) mengetahui nilai densitas, viskositas, titik kabut, kalor serap minyak, bau, warna dan kepekaan api, pada minyak hasil pirolisis sampah plastik dari kondensor satu dan dua yang diadsorpsi menggunakan zeolit dan arang aktif, (2) mengetahui kandungan yang terdapat pada minyak hasil pirolisis sampah plastik yang diadsorpsi menggunakan zeolit dan arang aktif, (3) mengetahui perbedaan ketrampilan berpikir kritis antara siswa yang belajar menggunakann model pembelajaraan inkuiri terbimbing dengan siswa yang belajar secara konvensional pada pembelajaran fisika. Pengkonversian sampah plastik menjadi bahan bakar minyak menggunakan proses pirolisis dengan dua kondensor air, kemudian minyak hasil pirolisis sampah plastik diadsorpsi menggunakan zeolit dan arang yang telah diaktifkan. Hasil penelitian menunjukkan nilai densitas minyak yang telah diadsorpsi untuk kondensor satu bernilai $772 \mathrm{Kg} / \mathrm{m}^{3}$ dan kondensor dua $770 \mathrm{Kg} / \mathrm{m}^{3}$, nilai viskositas minyak yang telah diadsorpsi
\end{abstract}


dari hasil kondensor satu dan dua bernilai sama yaitu $0,49 \mathrm{~m}^{2} / \mathrm{s}$, nilai titik kabut minyak yang telah diadsorpsi pada hasil kondensor satu dan dua bernilai sama yaitu $-18^{\circ} \mathrm{C}$, nilai kalor serap minyak, warna, bau, dan kepekaan api menunjukkan semakin banyak adsorben dan semakin lama proses adsorpsi maka, kalor serap minyak semakin kecil, warna yang terjadi semakin jernih, bau yang terjadi semakin tidak menyengat, dan kepekaan api semakin kecil. Hasil uji GC-MS didapatkan senyawa terbanyak yang terkandung dalam minyak pirolisis sampah plastik yang telah diadsorpsi yaitu 1,3,5trimethylcyclohexene. Implementasi pembelajaran fisika pada konsep kalor menunjukkan terdapat perbedaan hasil ketrampilan berpikir kritis pada kelas kontrol dan eksperimen. Berdasarkan uji beda pada hasil postest materi pertama didapatkan 0,022 dan postest materi kedua sebesar 0,047 , nilai tersebut lebih kecil dari taraf signifikasi 0,05 sehingga Ha diterima.

Kata Kunci: Arang Aktif, Kalor, Ketrampilan Berpikir KritsiS, Pirolisis, Zeolite, ,

\section{PENDAHULUAN}

Energi merupakan bagian tak terhindarkan dari masyarakat saat ini. Pemenuhan setiap pekerjaan tergantung pada energi. Namun bahan bakar fosil sebagai sumber energi seperti minyak sangat terbatas (Mahmud, 2013). Di Indonesia cadangan dan produksi bahan bakar minyak bumi (fosil) mengalami penurunan $10 \%$ setiap tahunnya, dan untuk tingkat konsumsi minyak rata-rata naik $6 \%$ pertahun.

Permasalahan lain yang terjadi selain menipisnya kebutuhan bahan bakar minyak yaitu terjadinya fenomena tingginya jumlah sampah dilingkungan. Data Kementrian Lingkungan Hidup (2015) mengatakan jumlah peningkatan timbunan sampah di Indonesia telah mencapai 175.000 ton/hari atau setara 64 juta ton/tahun.

Kualitas minyak hasil pirolisis sampah plastik dapat ditingkatkan kualitasnya melalui proses adsorpsi menggunakan media zeolit dan arang aktif. Zeolit bersifat adsorbent dimana dapat menyerap solut yang berupa gas atau liquid yang terdapat dalam suatu campuran (Udyani dan Wulandar, 2014). Zeolit mempunyai kapasitas yang tinggi sebagai penyerap. Hal ini disebabkan karena zeolit dapat memisahkan molekul-molekul berdasarkan ukuran dan konfigurasi dari molekul. Mekanisme absorpsi yang mungkin terjadi adalah absorpsi fisika (melibatkan gaya Van der Walls), absorpsi kimia (melibatkan gaya elektrostatik), ikatan hidrogen dan pembentukan kompleks koordinasi
(Andrean dan Masduqi dalam Affandi dkk, 2012)

Arang aktif juga mempunyai sifat yang sama seperti zeolit yaitu bersifat absorbent. Arang aktif mempunyai daya serap/adsorpsi yang tinggi terhadap bahan yang berbentuk larutan atau uap. Arang aktif dapat dibuat dari bahan yang mengandung karbon baik organik atau anorganik, tetapi biasa beredar di pasaran berasal dari tempurung kelapa, kayu dan batubara. Dalam jumlah kecil arang aktif digunakan juga sebagai katalisator. Sifat adsorpsinya selektif, dan bergantung pada besar atau volume pori-pori dan luas permukaan. Daya serap arang aktif sangat besar, yaitu 25$100 \%$ terhadap berat arang aktif (Suhartana, 2012)

Proses konversi sampah plastik menjadi bahan bakar melalui proses pirolisis dan penyaringannya dengan media zeolit dan arang aktif, kiranya dapat mengatasi persoalan sampah plastik dan keterbatasannya bahan bakar minyak yang ada. Proses konversi sampah menjadi minyak/bahan bakar adalah termasuk proses kimia dan juga proses fisika. Proses ini penting untuk diketahui oleh para siswa, khususnya pada matapelajaran fisika konsep kalor. Penyampaian konsep-konsep fisika agar mudah dipahami dengan baik dan benar oleh siswa maka pegajaran fisika harus dititikberatkan pada peran siswa secara aktif (Mulyasa dalam Zurkanain dan Suliyanah, 2014). Hal ini berkaitan pula dengan tujuan pembelajaran fisika yang 
telah dijabarkan dalam Standar Kompetensi dan Kompetensi Dasar dalam Permendiknas nomor 22 tahun 2007 tentang Standar Isi. Permendiknas tentang standar isi menyatakan bahwa fungsi dan tujuan mata pelajaran fisika di SMA dan MA adalah agar peserta didik memiliki kemampuan, salah satunya adalah memupuk sikap ilmiah yang mencakup: jujur, terbuka dalam menerima pendapat berdasarkan bukti bukti tertentu, kritis terhadap pernyataan ilmiah yaitu tidak mudah percaya tanpa ada dukungan hasil observasi empiris, serta dapat bekerjasama dengan orang lain (Asmawati, 2015). Dari penjabaran tersebut, agar pengetahuan konsep dapat tercapai dan siswa mempunyai ketrampilan berpikir kritis salah satunya yaitu dapat menggunakan model pembelajaran inkuiri terbimbing (guided inquiry) dimana tujuan utama model inkuiri terbimbing adalah mengembangkan keterampilan intelektual, berpikir kritis, dan mampu memecahkan masalah secara ilmiah (Wahyudin dan Sutikno dalam Asmawati, 2015)

\section{METODE}

Alat yang digunakan untuk penelitian ini adalah alat pirolisis yang komponennya terdiri dari tabung reaktor, pipa aliran uap, tabung air dan pipa minyak. Berikut gambar alat pirolisi sampah plastik.

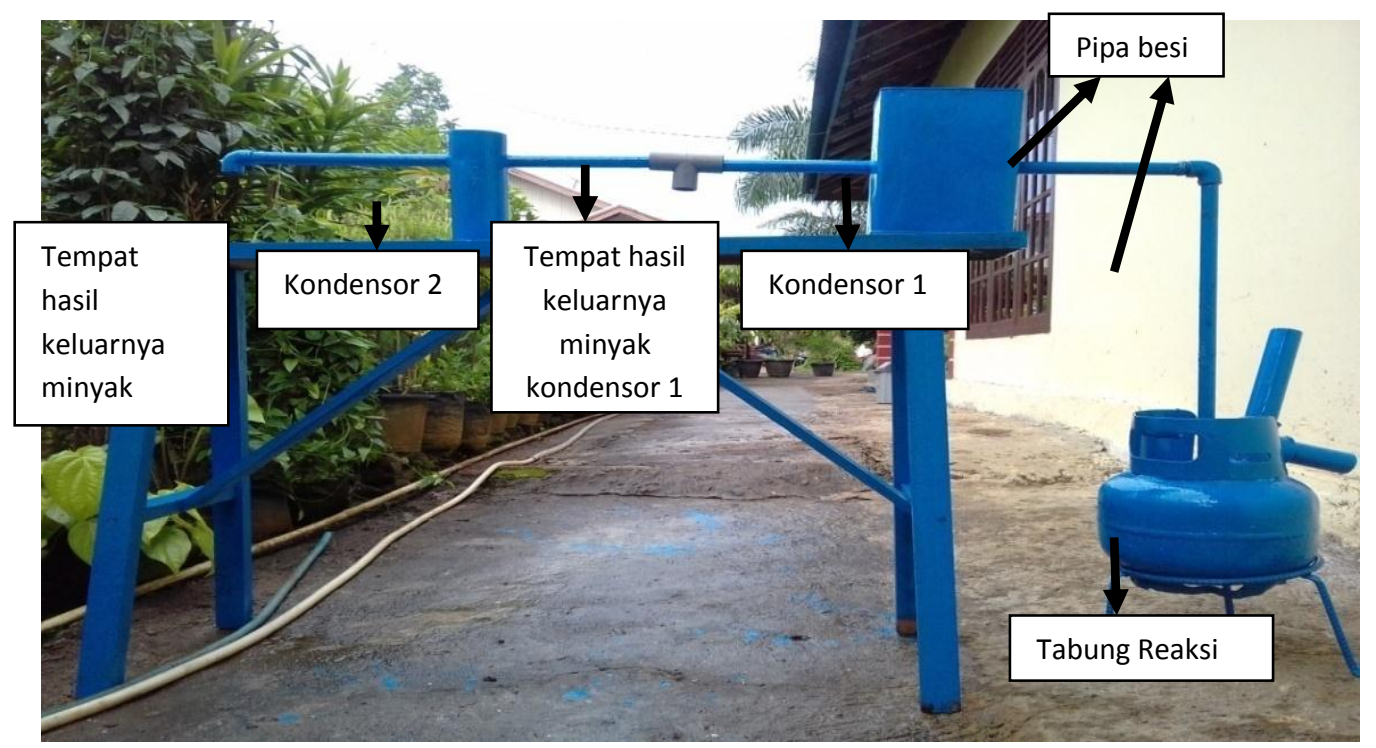

Gambar 1. Alat Pirolisis sampah plastik.

Pada penelitian ini dilakukan pemanasan sampah plastik jenis PP, Sehingga sampah akan terurai menjadi molekul sederhana berupa uap, kemudian di kondensasi melalui 2 tabung kondensor air. Dari kondensor ini akan dihasilkan minyak cair yang dipindahkan kedalam tabung penampungan. Setelah minyak cair sudah dalam tabung penampungan, langkah selanjutnya yaitu mengadsorpsi minyak hasil pirolisis sampah plastik menggunakan zeolit dan arang yang telah diaktifkan. Adsorpsi minyak sampah plastik ini diadsorpsi secara fungsi massa dan waktu. Pada fungsi massa minyak sampah plastik diadsorpsi dengan masing-masing adsorben dengan massa 50 gram, 100 gram, dan 150 gram. Pada fungsi waktu, minyak sampah plastik diadsorpsi dengan masing-masing adsorben bermassa 100 gram selama 8 jam dan diulangi sebanyak 8 kali pengukuran. Minyak yang telah diadsorpsi kemudian diukur densitas, viskositas, titik kabut, kalor serap minyak, bau, warna, kepekaan api dan kandungan yang terdapat dalam minyak.

Hasil penelitian kemudian diaplikasikan dalam proses pembelajaran 
dan dijadikan sebagai bahan dan alat praktikum pada konsep kalor materi pengaruh kalor terhadap perubahan wujud dan suhu benda pada kelas $X$ di SMA 3 Bengkulu Tengah

\section{HASIL DAN PEMBAHASAN}

\section{Uji sifat Minyak}

Uji sifat minyak ini meliputi uji viskositas, densitas, kepekaan api, kalori, warna, dan bau. Uji sifat minyak ini dilakukan setelah minyak di adsorpsi dengan adsorben. Dilihat dari hasil yang didapat, dari fungsi massa terlihat tidak terdapat perbedaan yang signifikan dari beberapa adsorben dan jumlah massanya. Jika dilihat dari fungsi waktu terdapat perbedaan dengan pertambahnya waktu absorsi. Dilihat dari sifat bensin, solar, dan minyak tanah, kecenderungan minyak pirolisis sampah plastik mendekati nilai fisis bensin. Berikut perbandingan bensin, solar, minyak tanah dan minyak pirolisis sampah plastik yang telah di adsorpsi terlihat pada Tabel 1.

Tabel 1. Tabel Perbedaan Uji Fisis Minyak Bahan Bakar

\begin{tabular}{|c|r|r|r|c|c|}
\hline Sifat fisis & Bensin & $\begin{array}{r}\text { Minyak } \\
\text { tanah }\end{array}$ & Solar & $\begin{array}{c}\text { Minyak pirolisis } \\
\text { kondensor satu }\end{array}$ & $\begin{array}{c}\text { Minyak pirolisis } \\
\text { kondensor dua }\end{array}$ \\
\hline Viskositas $\left(\mathrm{m}^{2} / \mathrm{s}\right)$ & 0,65 & 0,29 & 0,20 & 0,49 & 0,49 \\
\hline Densitas $\left(\mathrm{kg} / \mathrm{m}^{3}\right)$ & 715 & 780 & 820 & 772 & 770 \\
\hline
\end{tabular}

\section{Kalor Serap minyak}

Nilai kalor serap minyak ini sebagai alternatif pengganti nilai kalor minyak. Nilai kalor minyak tidak dapat diukur dengan menggunakan tes bom kalorimeter, sehingga sebagai alternatifnya digunakan $25 \mathrm{ml}$ minyak pirolisis sampah plastik yang telah diadsorpsi oleh adsorben untuk mendidikan $250 \mathrm{ml}$ air sampai minyak yang digunakan untuk mendidikan tersebut habis. Berikut grafik pengaruh massa adsorben terhadap kalor serap minyak pada pirolisis minyak sampah plastik yang telah diadsorpsi pada Gambar 2:

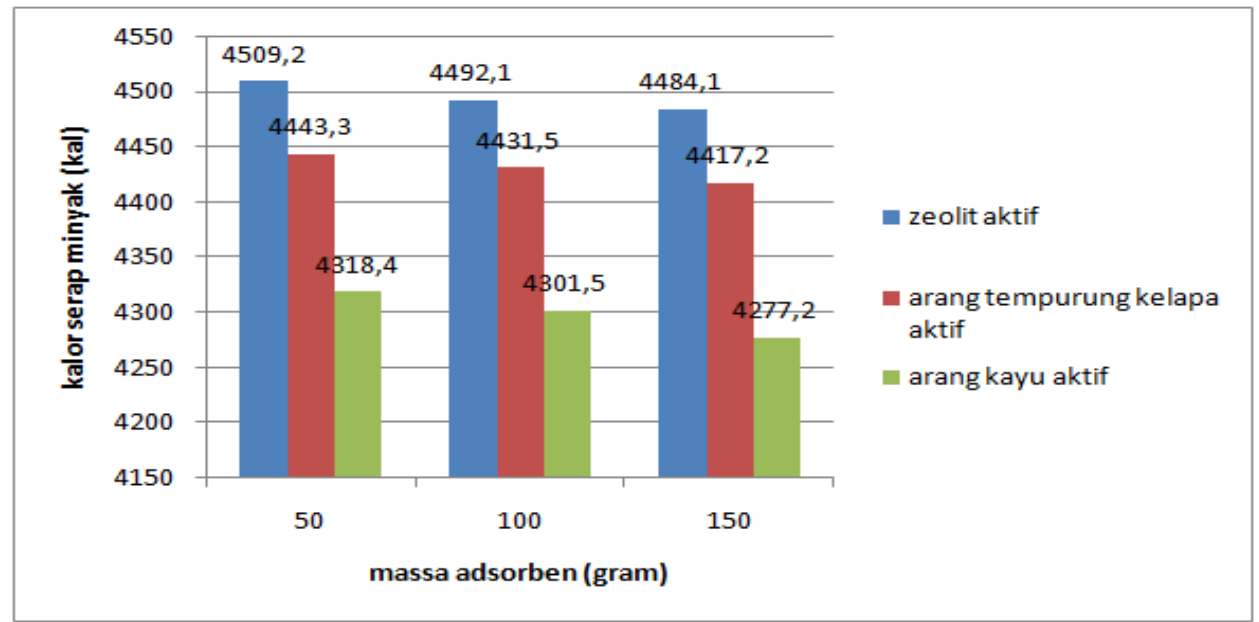

Gambar 2. Grafik pengaruh massa adsorben dengan nilai kalor serap minyak kondensor 2

Hasil kalor serap minyak yang didapat menunjukan minyak yang diadsorpsi oleh zeolit dengan massa 50 g memiliki kalor serap minyak yang paling besar. Perbedaan tersebut kemungkinan terjadi dari perbedaan komposisi masing-masing minyak yang telah diadsorpsi oleh masing-masing 
adsorben dengan jumlah dan waktu adsorpsi yang berbeda-beda.rikan nilai

Banyaknya bahan bakar yang terpakai menunjukkan hubungan bahwa semakin banyak bahan bakar yang dipakai akan memberikan nilai kalor yang semakin kecil dan semakin memperlambat kecepatan pembakaran. Dengan demikian jumlah bahan bakar yang terpakai juga merupakan indikator akan hemat atau borosnya bahan bakar. Semakin banyakknya bahan bakar yang terpakai maka semakin banyak bahan bakar yang dibutuhkan pada suatu proses pembakaran, dan semakin sedikit bahan yang terpakai menandakan semakin hemat bahna bakar yang digunakan dalam proses pembakaran. Menurut Sri Hartati (2010) semakin tinggi nilai kalor, maka panas yang dihasilkan semakin tinggi. Hal ini sama dengan kalor serap minyak, semakin besar kalor serap, maka nilai kalor dan panas yang dihasilkan semakin lama. sehingga bahan bakar dengan nilai kalor tinggi akan semakin kecil nilai kecepatan pembakaran dan jumlah bahan bakar yang digunakan semakin sedikit.

Jika ditinjau dari segi ekonomis, bahan bakar alternatif minyak pirolisis sampah plastik yang diadsorpsi dengan zeolite yang bermassa 50 gram dapat diajukan sebagai bahan bakar, karna mampu memasak air dalam waktu yang singkat dengan massa bahan bakar yang sedikit.

\section{Analisis GC-MS}

Hasil analisis GC-MS didapatakan delapan senyawa. Delapan senyawa tersebut mudah terbakar. Diantara delapan senyawa tersebut, 1,3,5-trimethylcyclohexene merupakan senyawa terbanyak yang terkandung pada minyak pirolisis sampah plastik yang telah diadsorpsi. 1,3,5trimethylcyclohexene merupakan senyawa mudah terbakar dengan bau tajam, merusak lingkungan dan mudah terbakar (Campbell.2012).

\section{Ketrampilan Berpikir Kritis}

Penelitain ini dilakukan sebanyak $4 \mathrm{x}$ pertemuan untuk masing-masing kelas kontrol dan eksperimen, dengan rincian 2 kali pertemuan untuk pretest dan 2 kali pertemuan untuk memberikan perlakukan dan posttest. Peneliti menggunakan dua kelas yang dijadikan sebagai sampel penelitian, yaitu X IPA 1 sebagi kelas eksperimen dan kelas $X$ ipa 4 sebagai kelas kontrol yang ditetapkan sebelum awal penelitian dilakukan. Soal pretest dan posttest memiliki kisi-kisi yang sama namun urutan soal dibedakan untuk menghindari siswa menghafal soal saat pretest.

Kelas $X$ ipa1 sebagai kelas eksperimen yang dalam pembelajarannya menggunakan model pembelajaran inkuiri terbimbing. Salah satu yang membedakan pembelajaran antar kelas eksperimen dan kelas kontrol adalah pada setiap pertemuan siswa diberikan lembar kerja siswa (LKPD) yang sesuai dengn pengembangan ketrampilan berpikir kritis. Pada kelas kontrol peneliti tidak memberikan LKPD namun soal yang diberikan kepada kelas kontrol sama dengan kelas eksperimen.

Pelaksanaan tes untuk mengukur keterampilan berpikir kritis siswa dilaksanakan setelah melakukan proses pembelajaran dengan menggunakan model pembelajaran inkuiri terbimbing. Keterempilan berpikir kritis siswa dapat diukur dan dilihat dari hasil tes posttest yang diberikan. Tingkat keterampilan ini ditinjau berdasarkan keterampilan berpikir kritis melalui indikator keterampilan berpikir kritis yang digunakan. Keterampilan berpikir kritis siswa pada penelitian ini menggunakan 5 indikator keterampilan berpikir kritis yaitu yaitu: a) kemampuan memfokuskan masalah, b) menganalisis argumen, c) mempertimbangkan kredibilitas suatu sumber, d) membuat dedukasi dan mempertimbangkan hasil deduksi, dan e) mengidentifikasi asumsi.Nilai keterampilan berpikir kritis siswa perindikator dapat dilihat pada tabel 2 dan tabel 3. 
Tabel 2. Nilai keterampilan berpikir kritis siswa perindikator materi pertama

\begin{tabular}{|c|c|c|c|c|c|c|c|c|}
\hline \multirow[b]{2}{*}{ No } & \multirow[b]{2}{*}{ Indikator } & \multirow[b]{2}{*}{$\begin{array}{l}\text { Skor } \\
\text { Ideal }\end{array}$} & \multicolumn{3}{|c|}{ Eksperimen } & \multicolumn{3}{|c|}{ Kontrol } \\
\hline & & & $\begin{array}{r}\text { Jumlah } \\
\text { Skor } \\
\text { Siswa }\end{array}$ & $\bar{x}$ & $\%$ & $\begin{array}{r}\text { Jumlah } \\
\text { Skor } \\
\text { Siswa }\end{array}$ & $\bar{x}$ & $\%$ \\
\hline 1 & $\begin{array}{l}\text { (Elemntery clarification) } \\
\text { Kemampuan } \\
\text { memfokuskan } \\
\text { pertanyaan }\end{array}$ & 20 & 445 & 14,8 & 74,2 & 385 & 12,8 & 64,2 \\
\hline 2 & $\begin{array}{l}\text { (Elemntery clarification) } \\
\text { Menganalisis argumen. }\end{array}$ & 20 & 355 & 11,8 & 59,2 & 350 & 11,6 & 58,3 \\
\hline 3 & $\begin{array}{l}\text { (Basic support) } \\
\text { Mempertimbangkan } \\
\text { kredibilitas suatu } \\
\text { sumber }\end{array}$ & 20 & 395 & 13,2 & 65,3 & 360 & 12 & 60 \\
\hline 4 & $\begin{array}{l}\text { (inference) } \\
\text { Membuat } \\
\text { Deduksi dan } \\
\text { mempertimbangkan } \\
\text { hasil deduksi }\end{array}$ & 20 & 355 & 11,8 & 59,2 & 325 & 10,8 & 54,2 \\
\hline 5 & $\begin{array}{l}\text { (Advance } \\
\text { clarification) } \\
\text { Mengidentifikasi asumsi. }\end{array}$ & 20 & 350 & 11,6 & 58,3 & 295 & 9,8 & 49,2 \\
\hline
\end{tabular}

\begin{tabular}{|c|c|c|c|c|c|c|c|c|}
\hline \multirow[b]{2}{*}{ No } & \multirow[b]{2}{*}{ Indikator } & \multirow[b]{2}{*}{$\begin{array}{l}\text { Skor } \\
\text { Ideal }\end{array}$} & \multicolumn{3}{|c|}{ Eksperimen } & \multicolumn{3}{|c|}{ Kontrol } \\
\hline & & & $\begin{array}{r}\text { Jumlah } \\
\text { Skor } \\
\text { Siswa }\end{array}$ & $\bar{x}$ & $\%$ & $\begin{array}{r}\text { Jumlah } \\
\text { Skor } \\
\text { Siswa }\end{array}$ & $\bar{x}$ & $\%$ \\
\hline 1 & $\begin{array}{l}\text { (Elemntery clarification) } \\
\text { Kemampuan } \\
\text { memfokuskan pertanyaan }\end{array}$ & 20 & 505 & 16,8 & 84,2 & 450 & 15 & 75 \\
\hline 2 & $\begin{array}{l}\text { (Elemntery clarification) } \\
\text { Menganalisis argumen. }\end{array}$ & 20 & 420 & 14 & 70 & 375 & 12,5 & 62,5 \\
\hline 3 & $\begin{array}{l}\text { (Basic support) } \\
\text { Mempertimbangkan } \\
\text { kredibilitas suatu sumber }\end{array}$ & 20 & 435 & 14,5 & 72,5 & 415 & 13,8 & 69,2 \\
\hline 4 & $\begin{array}{l}\text { (inference) } \\
\text { Membuat } \\
\text { Deduksi dan } \\
\text { mempertimbangkan } \\
\text { hasil deduksi }\end{array}$ & 20 & 365 & 12,2 & 60,8 & 360 & 12 & 60 \\
\hline 5 & $\begin{array}{l}\text { (Advance } \\
\text { clarification) } \\
\text { Mengidentifikasi asumsi. }\end{array}$ & 20 & 340 & 11,3 & 56,7 & 320 & 10,6 & 53,3 \\
\hline
\end{tabular}

Tabel 3. Nilai keterampilan berpikir kritis siswa perindikator materi kedua

Tabel 2 dan Tabel 3 menunjukkan bahwa terdapat perbedaan perolehan nilai rata-rata ketrampilan berpikir kritis fisika siswa kelas eksperimen dan kontrol yang ditinjau dari lima indikator berpikir kritis. Pada tabel terlihat bahwa nilai rata-rata kemampuan berpikri kritis fisika kelas eksperimen lebih tinggi daripada nilai rata-rata kelas kontrol untuk setiap indikatornya, hal tersebut menunjukkan bahwa siswa pada kelas eksperimen memiliki ketrampilan berpikir kritis fisika yang yang lebih tinggi dibandingkan dengan kelas kontrol.

Dari tabel diatas terlihat nilai rata-rata keterampilan berpikir kritis siswa dengan 
menerapkan indikator keterampilan berpikir kritis melalui model inkuiri terbimbing. Pada materi satu keterampilan berpikir kritis, siswa lemah pada indikator IV yaitu membuat dedukasi dan mempertimbangkan hasil dedukasi. Hal ini di karenakan pada tahap tersebut soal keterampilan berpikir kritis berupa diagram yang meminta siswa untuk menganalisis dan meminta siswa memberikan kondisi yang logis dalam diagram serta dapat menginterpretasikan pernyataan yang tepat dari sebuah diagram yang diberikan. Hampir seluruh siswa kurang memahami pembacaan dalam diagram tersebut.

Pada materi kedua keterampilan berpikir kritis, siswa masih lemah pada indikator IV. Siswa kurang bisa mendeduksi dari suatu permasalahan yang diberikan.Selain keberhasilan keterampilan berpikir kritis siswa tergantung dengan kemampuan siswa dalam bersikap mau berpikir secara mendalam tentang hal-hal yang berada dalam jangkauan siswa. Hal ini sesuai dengan definisi keterampilan berpikir kritis yang dikemukakan oleh Glaser dalam Fisher (2009: 3), mendefinisikan berpikir kritis sebagai: a) suatu sikap mau berpikir secara mendalam tentang masalah-masalah dan hal-hal yang berada pada jangkauan pengalaman seseorang, b) pengetahuan tentang metode-metode penilaian dan penalaran yang logis; dan, c) keterampilan untuk menerapkan metode-metode tersebut.

\section{KESIMPULAN}

Berdasarkan hasil penelitian yang
telah dilakukan dan analisa data
terhadap hasil penelitian, maka dapat
ditarik kesimpulan sebagai berikut:

1. Hasil penelitian menunjukkan nilai densitas minyak yang telah diadsorpsi untuk kondensor satu bernilai $772 \mathrm{Kg} / \mathrm{m}^{3}$ dan kondensor dua bernilai $770 \mathrm{Kg} / \mathrm{m}^{3}$, nilai viskositas minyak yang telah diadsorpsi dari hasil kondensor satu dan dua bernilai sama yaitu $0,49 \mathrm{~m}^{2} / \mathrm{s}$, nilai titik kabut minyak yang telah diadsorpsi pada hasil kondensor satu dan dua bernilai sama yaitu $-18^{\circ} \mathrm{C}$, nilai kalor serap minyak, warna, bau, dan kepekaan api menunjukkan semakin banyak adsorben dan semakin lama proses adsorpsi maka, kalor serap minyak semakin kecil, warna yang terjadi semakin jernih, bau yang terjadi semakin tidak menyengat, dan kepekaan api semakin kecil.

2. Hasil GCMS minyak pirolisis sampah plastik yang telah diadsorpsi yaitu mengandung delapan senyawa. Senyawa yang terbanyak yaitu 1,3,5trimethylcyclohexene.

3. Terdapat perbedaan hasil ketrampilan berpikir kritis antara siswa yang belajar menggunakan model pembelajaran inkuiri terbimbing, dengan siswa yang belajar secara konvensional pada pembelajaran fisika di SMAN 3 Bengkulu Tengah tahun pelajaran 2016/2017. Dapat dilihat dari hasil yang diperoleh berdasarkan uji beda pada hasil postest materi pertama yaitu 0,022 dan pada postest materi kedua yaitu sebesar 0,047 . Nilai tersebut lebih kecil dengan taraf signifikasi 0,05 sehingga terdapat perbedaan hasil ketrampilan berpikir kritis pada kelas kontrol dan eksperimen.

\section{DAFTAR PUSTAKA}

Affandi, F dan Hadist, H. 2012. Pengaruh Metode Aktivasi Zeolite Alam Sebagai Bahan Penurunan Temperatur Campuran Beraspal Hangat. Jurnal Pusat Litbang Jalan dan Jembata. Diakses 6 April 2011

Asmawati,S.Y.K. 2015. Lembar Kerja Siswa (LKS) Menggunakan Model Guided Inquiry Untuk Meningkatkan Keterampilan Berpikir Kritis Dan Penguasaan Konsep Siswa. Jurnal Pendidikan Fisika (JPI): 2442-4838

\section{Campbell, L. 2012. Ullmann's} Encyclopedia of Industrial chemistry. Exxon Chemical Co. doi:10.1002/14356007.a08_209.pu b2 
Fisher, A. 2009. Berpikir Kritis Sebuah Pengantar. Jakarta : Erlangga

Jihad.A dan Haris.A. 2012. Evaluasi Pembelajaran. Yogyakarta: Multipresindo

Mahmud. K. 2013. Fuel Cell and Renewable Hydrogen Energy to Meet Household Energy Demand. International Journal of Advanced Science and Technology. Vol. 54. Di akses May 2013

Mandala W.W, Cahyono Sigit M, Ma'arif S, Sukarjo H B, Wardoyo. 2016. Pengaruh Suhu terhadap Rendemen dan Nilai Kalor Minyak Hasil Pirolisis Sampah Plastik. Jurnal Mekanika dan Sistem Termal, Vol. 1(2): 2527-3841. Diakses Agustus 2016

Said M, Prawati W.A, Dan Murenda E. 2008. Aktifasi Zeolit Alam Sebagai Adsorbent Pada Adsorpsi Larutan lodium. Jurnal Teknik Kimia, No. 4, Vol. 15. Diakses Desember 2008
Suhartana. 2012. Pemanfaatan Tempurung Kelapa Sebagai Bahan Baku Arang Aktif dan Aplikasinya Untuk Penjernihan Air Sumur di Desa Belor Kecamatan Ngaringan Kabupaten Grobogan. Laboratorium Kimia Organik FMIPA UNDIP. Vol. 9, No. 3 Juli 2006, hal. 151-156. ISSN : $1410-$ 9662

Udyani K, dan wulandari Y. 2014. Aktivasi zeolit alam untuk peningkatan kemampuan sebagai adsorben pada pemurnian biodiesel. Seminar Nasional Sains dan Teknologi Terapan II 2014 Institut Teknologi Adhi Tama Surabaya, 978-602-98569-1-0

Wahyudi, E.L dan Supardi, I.A.Z. 2013. Penerapan Model Pembelajaran Inkuiri Terbimbing Pada Pokok Bahasan Kalor Untuk Melatihkan Keterampilan Proses Sains Terhadap Hasil Belajar Di SMAN 1 Sumenep. Jurnal Inovasi Pendidikan Fisika. Vol 02 No 02 Hal: $62-65$ 